\title{
The larva of Oecetis tripunctata (Fabricius, I793) (Trichoptera, Leptoceridae)
}

\author{
Johann Waringer', Wolfram Graf² \\ I Department of Limnology and Oceanography, Faculty of Life Sciences, University of Vienna 2 Institute of \\ Hydrobiology and Aquatic Ecology Management, University of Natural Resources and Applied Life Sciences, \\ Vienna, Austria
}

Corresponding author: Johann Waringer (johann.waringer@univie.ac.at)

Academic editor: R. Holzenthal | Received 23 June 2014 | Accepted 17 September 2014 | Published 13 October 2014

http://zoobank.org/7F914033-8C31-4A64-A595-0949A1E3A1EA

Citation: Waringer J, Graf W (2014) The larva of Oecetis tripunctata (Fabricius, 1793) (Trichoptera, Leptoceridae). ZooKeys 445: 117-126. doi: 10.3897/zookeys.445.8153

\begin{abstract}
Oecetis tripunctata is a widely distributed leptocerid in Europe, ranging from the Iberian and Apennine peninsulas and the Central and Western European highlands to the plains of Eastern Europe. The long, single-bladed mandibles are indicative for a predacious lifestyle. This paper describes the previously unknown larva of Oecetis tripunctata. Information on the morphology of the 5th larval instar is given, and the most important diagnostic features are illustrated. A synoptic key for the European species of Oecetis is also provided. In the context of existing identification keys the larva of $O$. tripunctata keys together with $O$. intima and $O$. notata. Oecetis tripunctata is separated from the other two species by the fact that a double row of long setal fringes is lacking at the hind tibiae and that several long setae are present on the protrochantinus.
\end{abstract}

\section{Keywords}

Description, distribution, larva, identification, West Paleartic fauna

\section{Introduction}

From Europe, ten species of genus Oecetis McLachlan, 1877 are known (Malicky 2004, 2005). However, the larvae of only seven species were described up to now: Oecetis furva (Rambur), O. intima McLachlan, O. lacustris (Pictet), O. notata (Rambur), O. ochracea (Curtis), O. struckii Klapálek (unvalid synonym = Paroecetis Lestage) 
and $O$. testacea (Curtis). References for the larval descriptions available are listed in Table 1. The larvae of $O$. canariensis Brauer, O. grazalemae Gonzalez \& Iglesias and $O$. tripunctata (Fabricius) were unknown. Recently, however, W. Graf managed to collect larvae of $O$. tripunctata at the Thaya river in the northern part of Lower Austria. Oecetis tripunctata is a widely distributed leptocerid in Europe, ranging from the British Isles and the Iberian and the Apennine peninsulas and the Central and Western European highlands to the plains of Eastern Europe (Graf et al. 2008). Across Asia, this species ranges even to Bali, with many records in the countries between. Oecetis tripuncatata is probably the caddisfly species with the widest distribution range currently known worldwide (Malicky 2005, 2009). This taxon was described by Fabricius (1793) in the genus Phryganea, redescribed as Setodes punctatella (Rambur, 1842), as Oecetis buitenzorgensis (Ulmer, 1951) and as O. alexanderi (Kumanski, 1976). Oecetis buitenzorgensis was declared as synonym of $O$. tripunctata (Fabricius, 1793) by Malicky (2009b) whereas $O$. alexanderi was declared as synonym of $O$. tripunctata by Kumanski (1988) (Yang and Morse 2000; Morse 2014). With our description of its larva, proposed here, the identification of eight out of ten European Oecetis species is now possible even without an adult male as frequently practiced within caddisflies studies.

\section{Material and methods}

The larvae were sampled on 18 December 2012 by Wolfram Graf in the Thaya river at Hohenau, a short distance upstream of its confluence with the March river in Lower Austria. The catchment of the Thaya is situated within the granite and gneiss complex of the Bohemian highlands. Due to its low slope, the river meanders strongly and has created some scenic, deeply carved valleys descending up to $150 \mathrm{~m}$ steeply downwards from the plateau of the surrounding highlands. The watershed area of the Thaya is $13.319 \mathrm{~km}^{2}$ with an average discharge of $43.9 \mathrm{~m}^{3} \mathrm{~s}^{-1}$ and a Strahler stream order of seven. Some river stretches of the Thaya situated within the Czech Republic have been transformed in reservoirs used for irrigation, drinking water supply and hydroelectric power plants (Waringer 2003). A hand net was used to collect larvae of Oecetis tripunctata in the Thaya river at Hohenau in the northern part of the federal state of Lower Austria on 18 December 2012 (4836'04"N, 16 ${ }^{\circ} 56^{\prime} 10^{\prime} \mathrm{E}, 161 \mathrm{~m}$ above sea level). The material was preserved in 70\% ethanol. A Nikon Labophot 2 microscope and a Nikon SMZ 1500 binocular microscope with DS-Fi1 camera and NIS-elements D 3.1 image stacking software for combining 8-42 frames in one focused image were used to study and photograph the larvae.

Species association was enabled by the fact that all other five Oecetis species reported from Austria (Malicky 2009a: Oecetis furva, O. lacustris, O. notata, O. ochracea, O. testacea) are well known in the larval stage (e.g., Wallace et al. 2003; Waringer and Graf 2011), and the new taxon is morphologically very different from the other species. Additionally, close to our larval collecting site more than 300 adults of $O$. tripunctata were sampled by mobile light traps. 
The 5th instar larvae of O. tripunctata are deposited in the collection of J. Waringer (Vienna, Austria) and in the collection of W. Graf (Vienna, Austria). Comparative material of other Oecetis species included the following 5 th instar larvae: Oecetis furva $(\mathrm{n}=$ 5), O. lacustris $(\mathrm{n}=2), O$. notata $(\mathrm{n}=6), O$. ochracea $(\mathrm{n}=2), O$. struckii $(\mathrm{n}=3)$ and $O$. testacea $(\mathrm{n}=3)$ (all taxa from the collection of J. Waringer, Vienna, Austria). We used the morphological terminology by Waringer and Graf (2011) and Wallace et al. (2003).

\section{Results}

Oecetis tripunctata (Fabricius, 1793)

Description of the 5 th instar larva

Diagnosis. Mandible sickle-shaped, with only one cutting edge; head capsule without distinct dark patches; hind tibiae without double row of long setal fringes; number of long setae on protrochantinus is $>1$; basal setae on 2 nd and 3rd tarsal claw rudimentary.

Biometry. Body length of 5 th instar larvae ranging from 2.7 to $4.5 \mathrm{~mm}$, head width from 0.66 to $0.70 \mathrm{~mm}(\mathrm{n}=15)$.

Head. Head capsule surface very smooth, roundish and hypognathous with pale yellow coloration. Light muscle attachment spots on frontoclypeus and parietalia very indistinct (Figs1-2). White ring present around eyes (Fig. 1). In addition to complete set of primary setae, head capsule densely covered by pale secondary setae, especially at anterolateral corners, dorsally of eyes and over frontoclypeus (Figs1, 4, 5). Frontoclypeus elongated, narrow, with very shallow central constriction at eye level (Figs1, 5). Subocular ecdysial line running from foramen occipitale to lateral section of parietalia, ventrally to the eyes. Anteriorly of the eyes the subocular ecdysial line bends dorsally, eventually meeting frontoclypeal suture (Fig. 1e). Antennae slender, approximately six times longer than its width at widest section, situated at extreme anterior end of parietalia and originating from a socket-like ridge (Fig. 5a). Labrum light brown, quadrangular, with anterior median notch (Fig. 1); in addition to 6 pairs of primary setae, with numerous secondary setae on dorsal surface (Fig. 1ss). Maxillary palps very long, distinctly protruding labrum (Fig. 2mp). Ventral apotome trapezoidal in shape (Fig. 2a), pale yellow with light brown anterior border; apotome not separating parietalia posteriorly. Mandibles single-bladed, sickle-shaped, with only 1 cutting edge; with sharp terminal tooth and 1-2 subapical secondary teeth (Fig. 3).

Thorax. Pronotum covering posterior section of head, light yellowish-brown, semitransparent, without distinct markings and muscle attachment spots (Fig. 5); dense continuous row of straight, pale setae along anterior border; pronotal surface densely covered by high number of pale setae (Figs 1, 4). Pleural sclerites pale, semicircular, with thin, blackish-brown ventral margins; anteriorly, with pale, large, ear-like protrochantin bearing numerous pale setae (Fig. 6p). Prosternal horn absent.

Mesonotum completely covered by two sclerites, yellowish and paler than pronotum, with distinct markings and muscle attachment spots (Figs 4, 5); dense cover of 

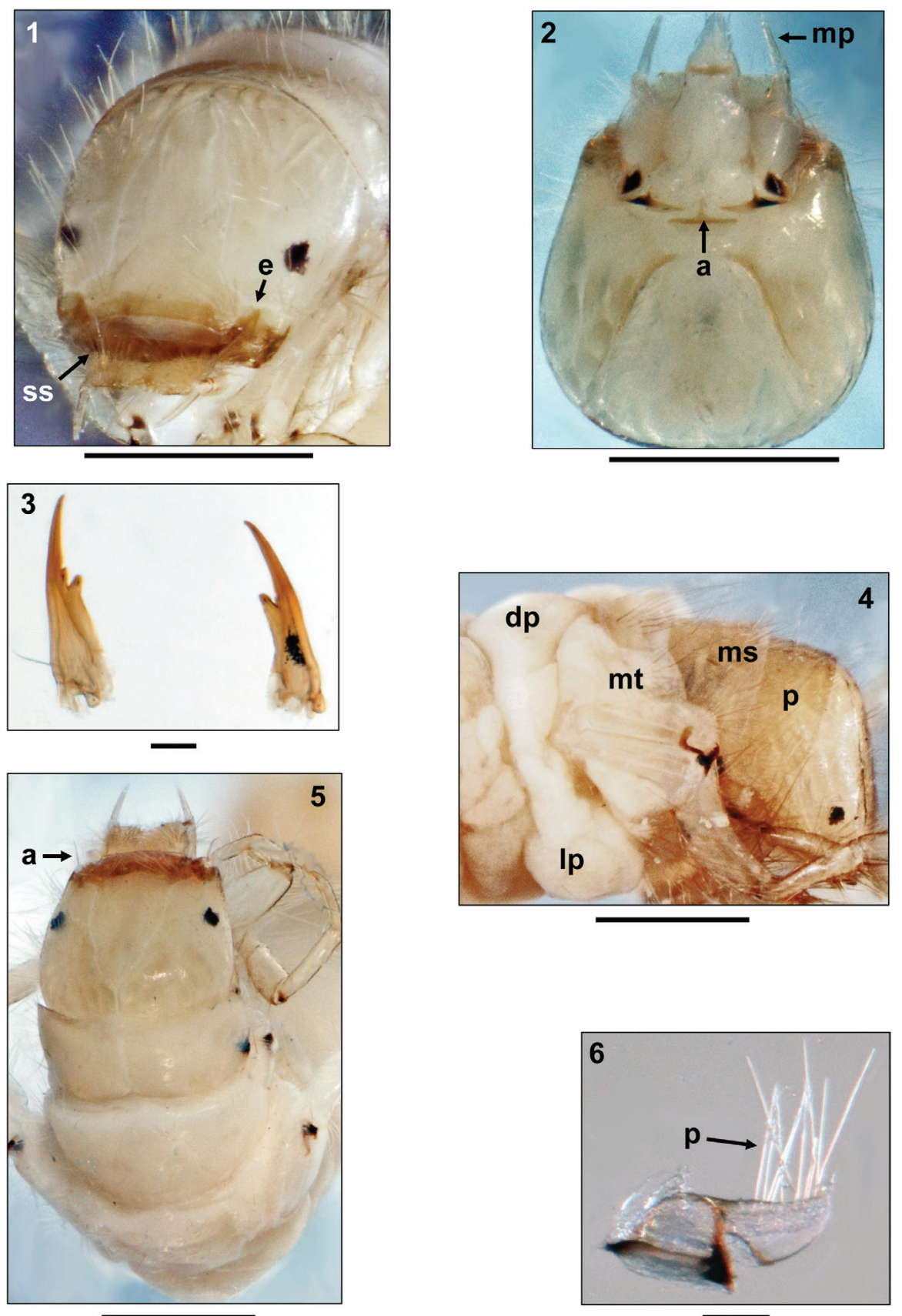

Figures I-6. Oecetis tripunctata (Fabricius, 1793), 5th instar larva. I Head, dorsal view (e = subocular ecdysial line bending dorsally and meeting frontoclypeal suture; ss = secondary setae on labrum) $\mathbf{2}$ Head, ventral view ( $\mathrm{a}=$ ventral apotome; $\mathrm{mp}=$ maxillary palp) 3 Mandibles, dorsal view $4 \mathrm{Head}$, thorax and 1 st abdominal segment, right lateral view $(\mathrm{p}=$ pronotum; $\mathrm{ms}=$ mesonotum; $\mathrm{mt}=$ metanotum; $\mathrm{dp}=$ dorsal protuberance; $1 \mathrm{p}=$ lateral protuberance) $5 \mathrm{Head}$ and thorax, dorsal view $(\mathrm{a}=$ antenna) $\mathbf{6}$ Right protrochantin, lateral view ( $\mathrm{p}=$ pale setae). Scale bars: $0.5 \mathrm{~mm}$ (except Figs 3, 6:0.1 mm). 

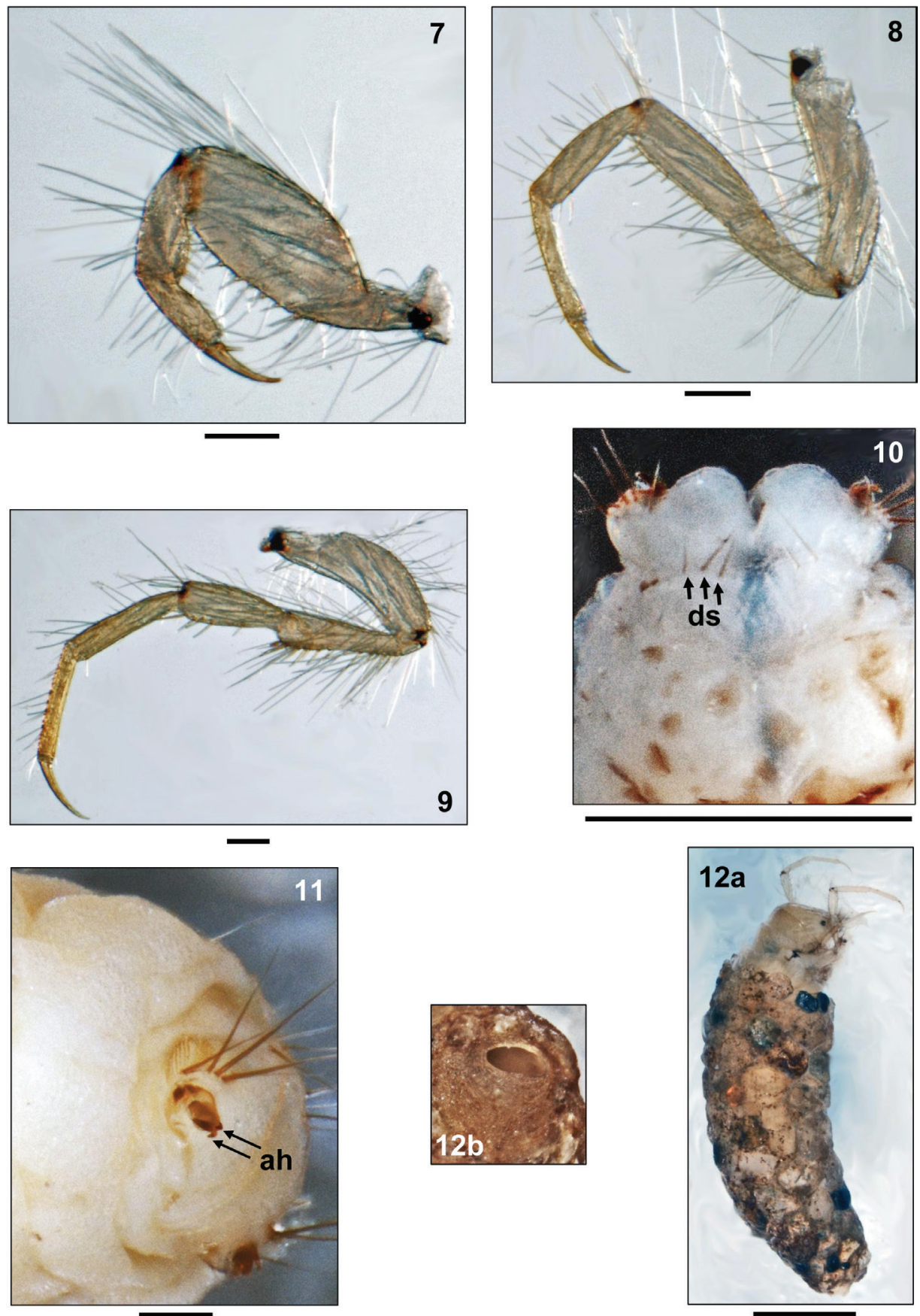

Figures 7-12. Oecetis tripunctata (Fabricius, 1793), 5th instar larva. 7 Left 1st leg, posterior view 8 Left 2nd leg, posterior view 9 Left 3rd leg, posterior view 10 Tip of abdomen, dorsal view (ds = dorsal setae) I I Tip of abdomen, left posterolateral view ( $\mathrm{ah}=2$ accessory hooks on anal claw) I 2a Larva and case, right lateral view I 2b Tip of larval case, posterior view. Scale bars: $0.1 \mathrm{~mm}$ (except Fig. 10: $0.5 \mathrm{~mm}$ and Fig. I I: $1 \mathrm{~mm})$. 
pale setae on the surface and along anterior border. Pleural sclerites pale, with thin, blackish-brown ventral margin (Fig. 4). Mesoventer without setae.

Metanotum without sclerotization except by pleural sclerites and with dense dorsal setal cover; pleural sclerites arrangement as on mesonotum (Fig. 4).

Legs yellowish, with very numerous setae, especially on coxae, trochanters and femora (Figs 7-9); tibiae and tarsi undivided and without central constrictions. Femur of foreleg much wider than those of mid- and hind legs. Claw of mid leg curved and not hook-shaped (Fig. 8). Long setal fringes for swimming lacking on hind legs; distal section of hind trochanter broadened and club-like (Fig. 9).

Abdomen. First abdominal segment with one dorsal (Fig. 4dp) and two lateral protuberances (Fig. 4lp), the latter with very pale and inconspicuous lateral sclerites. Lateral fringe present from segments 3-7, consisting of extremely short, pale hairs. Dorsum of 9 th abdominal segment with 6-8 setae (Fig. 10ds). Anal prolegs medium brown, anal claws dark brown, each with two small dorsal accessory hooks (Fig. 11ah). Anal region without rows of spines and tooth-edges plates (Fig. 11).

Gills single-filamented; dorsal gills present at most from 2nd segment (presegmental position) to 3rd segment (presegmental position); ventral gills only at 3rd segment (presegmental); lateral gills absent.

Case. Larval case 3.0-3.7 mm long ( $\mathrm{n}=15)$, curved, tapered (width at anterior opening $1.2-1.5 \mathrm{~mm}$ and at posterior opening $0.6-0.7 \mathrm{~mm}$ ), consisting of mix of mineral particles of unequal grain size (Fig. 12a). Posterior case opening partly closed by terminal silken membrane with oval foramen $0.2 \mathrm{~mm}$ wide and arranged transversally; ventral lip of membrane slightly protruding, creating an upward-directed twist of the foramen (Fig. 12b).

\section{Synoptic key for the currently known European Oecetis larvae (final instars; Table 1)}

Within genus Oecetis, O. tripunctata keys together with O. intima McLachlan, 1877 and O. notata (Rambur, 1842) (Table 1). Oecetis tripunctata is easily separated from the other two species by the fact that a double row of long setal fringes is lacking at the hind tibiae (Fig. 9) and that several long setae are present on the protrochantinus (Fig. 6).

\section{Biological remarks}

Our collection time of the larvae is in accordance with the reported spring to summer emergence and flight periods of the species; the emergence period is short and mostly limited to two months or less (Graf et al. 2008). In a light trap study from the nearby river March, we observed O. tripunctata to be on the wing only from June 27th to August 3rd (Waringer and Graf 2006).

As pointed out by Wiggins (1996), Oecetis larvae are bottom-dwellers covering a wide range of habitats from lentic to lotic environments and may be even collected from brackish 


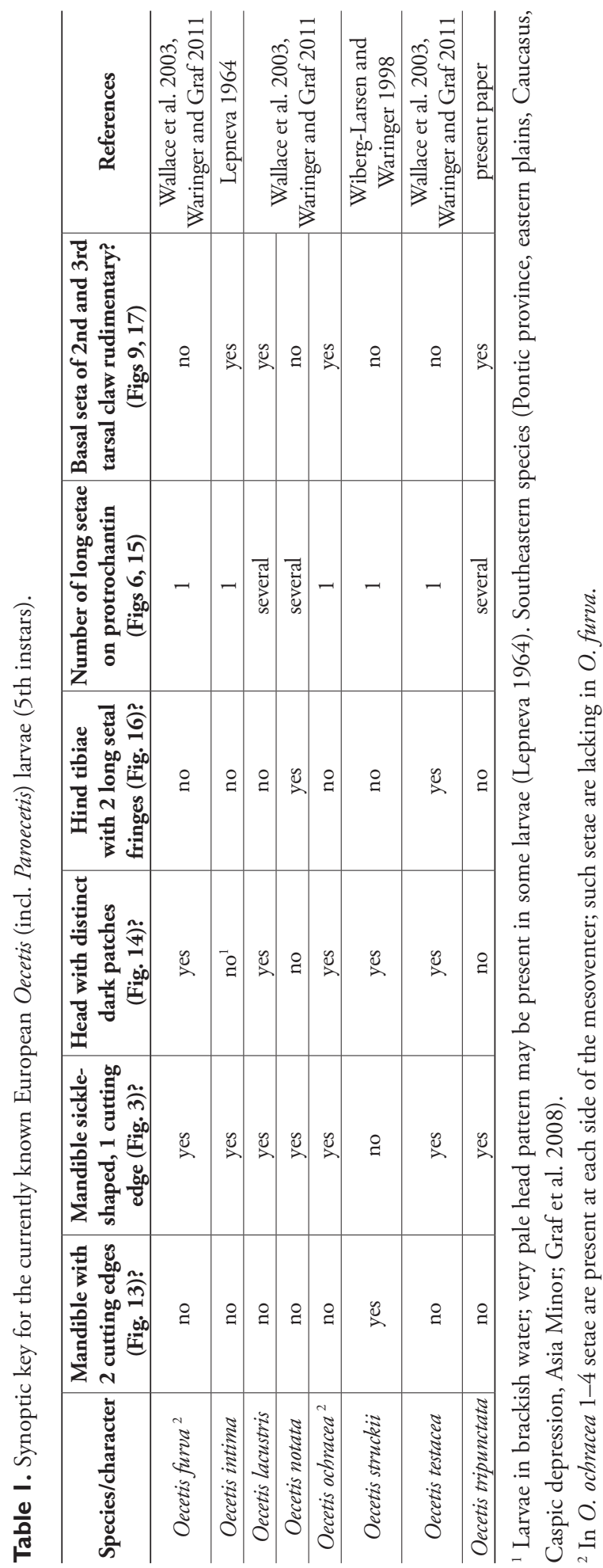



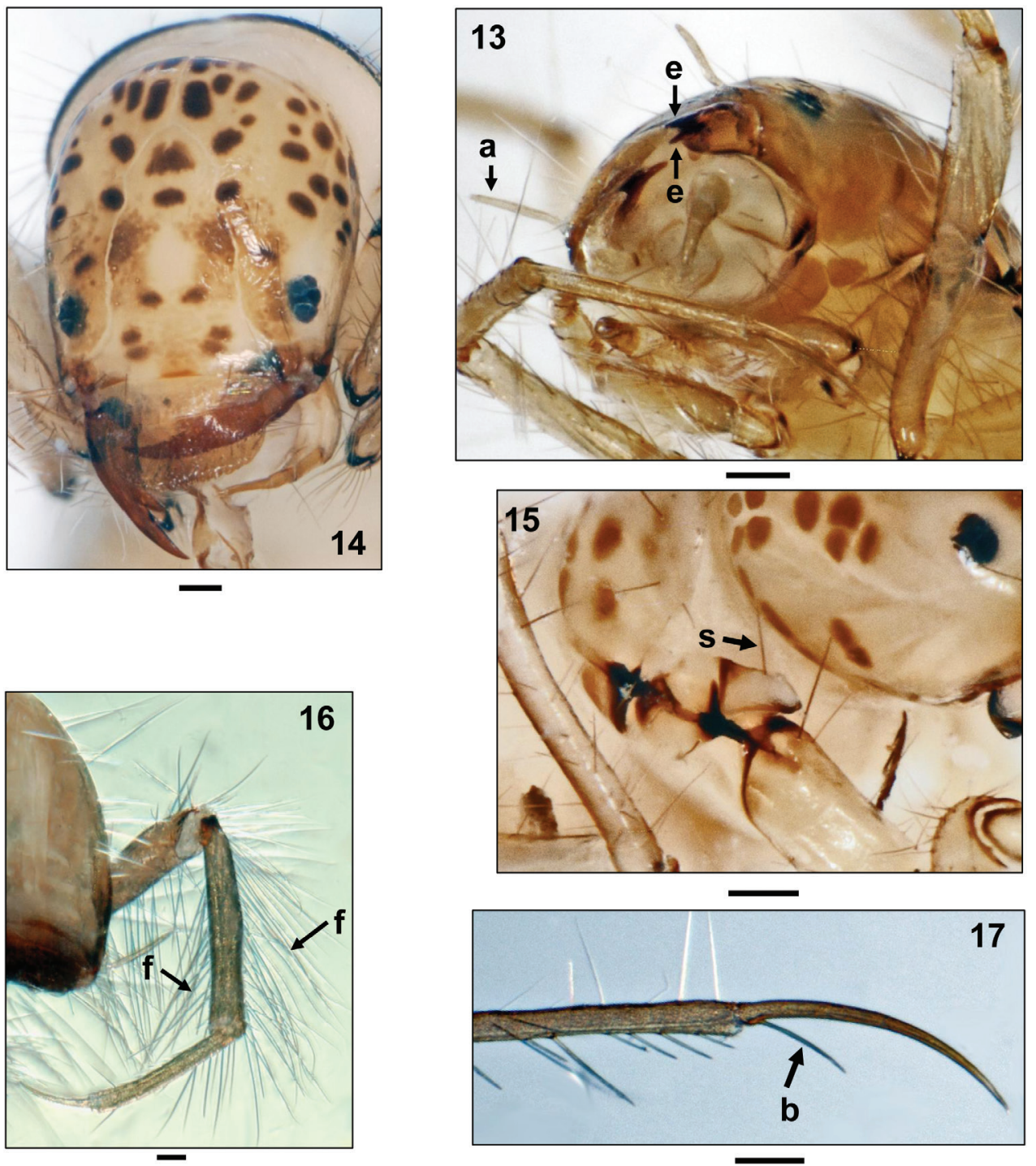

Figures I3-I7. I3 Oecetis struckii Klapálek, 1903, 5th instar larva, left ventrolateral view (a = antenna, $\mathrm{e}=$ two cutting edges of the mandible) I4 Oecetis testacea (Curtis, 1834), 5th instar larva, head, frontal view 15 Oecetis furva (Rambur, 1842), 5th instar larva, right propleuron, lateral view ( $\mathrm{s}=$ long seta on protrochantin) 16 Oecetis notata (Rambur, 1842), 5th instar larva, head and 3rd leg, frontolateral view ( $\mathrm{f}=$ two long setal fringes on hind tibia) 17 Oecetis furva (Rambur, 1842), 5th instar larva, distal section of right 3rd tarsus and claw $(\mathrm{b}=$ basal seta). Scale bars: $0.1 \mathrm{~mm}$.

waters (e.g., O. intima; Lepneva 1964). In Europe, the preferred habitats are lowland rivers with low current velocities, e.g. the Raab and the March systems in Austria.

The long, single-bladed predatory jaws of $O$. tripunctata and most other known Oecetis larvae are unusual among cased caddisflies; they are used for catching worms 
and chironomid larvae which are ingested whole (Wallace et al. 2003). Interestingly, O. struckii, once attributed to genus Paroecetis Lestage, is unique in that the mandibles are double-edged (Fig. 13, arrows). Nevertheless, Wiberg-Larsen and Waringer (1998) reported also for this Oecetis species only animal remains in the foregut (Testacea, Hydrachnellae, Oribatei, Cladocera, Asellus, Chironomidae).

\section{Acknowledgements}

This study was financially supported by the BioFresh EU project-Biodiversity of Freshwater Ecosystems: Status, Trends, Pressures and Conservation Priorities (contract No. 226874), the European Territorial Co-Operation Austria - Czech Republic 20072013 and the Austrian Federal Ministry for Agriculture, Forestry, Water Management and Environment.

\section{References}

Brauer F (1900) Über die von Prof. O. Simony auf den Canaren gefundenen Neuroptera und Pseudoneuroptera (Odonata, Corrodentia et Ephemeridae). Sitzungsberichte der Kaiserlichen Akademie der Wissenschaften (Wien) 109: 464-477.

Curtis J (1825) British Entomology; being illustrations and descriptions of the genera of insects found in Great Britain and Ireland: containing coloured figures from nature of the most rare and beautiful species, and in many instances of the plants upon which they are found, Volume IV. Hymenoptera, Part II. Neuroptera. Trichoptera. \#57: Leptocerus ochraceus. Printed for the author, sold by Ellis and Co., Bloomsbury; Simpkin and Marshall, Stationer's Court; and J.B. Bailliere, Regent Street.

Curtis J (1834) XXXVII: Descriptions of some hitherto nondescript British Species of Mayflies of Anglers. The London and Edinburgh Philosophical Magazine and Journal of Science 4: 212-218.

Fabricius JC (1793) Entomologia systematica emendata et aucta. Secundum classes, ordines, genera, species adjectis synonimis, locis, observationibus, descriptionibus (Tomus II). Impensis Christ. Gottl. Proft, Hafniae, 519 pp.

Gonzalez MA, Iglesias JC (1989) Une nouvelle espèce de Trichoptère du Sud de l'Espagne: Oecetis grazalemae (Trichoptera : Leptoceridae). Annales de Limnologie 25: 69-71. doi: 10.1051/limn/1989008

Graf W, Murphy J, Dahl J, Zamora-Muñoz C, López-Rodríguez MJ (2008) Volume 1 Trichoptera. In: Schmidt-Kloiber A, Hering D (Eds) Distribution and Ecological Preferences of European Freshwater Organisms. Pensoft Publishers, Sofia, Moscow, 388 pp.

Klapálek F (1903) Ueber drei wenig bekannte Micrasema-Arten und eine neue Oecetis. Sitzungsberichte der königlich böhmischen Gesellschaft der Wissenschaften 5: 1-8.

Kumanski K, Malicky H (1976) Contributions to the knowledge of the Bulgarian Trichoptera. Polskie Pismo Entomologiczne 46: 95-126. 
Kumanski K (1988) Fauna Bulgarica 19: Trichoptera, Integripalpia. In aedibus Akademiae Scientiarum Bulgaricae, Sofia, 353 pp.

LepnevaSG (1964) Fauna SSSR, Rucheiniki, Lichinki i kukolki podotryada tse'noshchupikovykh

[Fauna of the U.S.S.R., Trichoptera, larvae and pupae of Annulipalpia], volume II, No. 1 [translated by the Israel Program for Scientific Translations, Jerusalem, 1970]. Trudy Zoologicheskogo Instituta Akademii Nauk SSSR, Moscow/Leningrad (N.S.) 88: 1-638.

Malicky H (2004) Atlas of European Trichoptera, Second edition. Springer, Dordrecht, 359 pp. Malicky H (2005) Ein kommentiertes Verzeichnis der Köcherfliegen (Trichoptera) Europas und des Mediterrangebietes. Linzer biologische Beiträge 37: 533-596.

Malicky H (2009a) Rote Liste der Köcherfliegen Österreichs (Insecta: Trichoptera). In: Zulka KP (Ed.) Rote Liste gefährdeter Tiere Österreichs. Teil 14/3: Flusskrebse, Köcherfliegen, Skorpione, Weberknechte, Zikaden. Umweltbundesamt. Böhlau Verlag, Wien, 534pp.

Malicky H (2009b) Beiträge zur Kenntnis asiatischer Trichopteren. Braueria 36: 11-58.

McLachlan R (1877) A Monographic Revision and Synopsis of the Trichoptera of the European Fauna. John van Voorst and Friedlander \& Sohn, London and Berlin, 6, 281-348.

Morse JC (Ed.) (2014) Trichoptera World Checklist. http://entweb.clemson.edu/database/trichopt/index.htm [accessed 4 September 2014]

Pictet FJ (1834) Recherches pour Servír à l'Histoire et à l'Anatomie des Phryganides. Geneva, 235 pp. doi: 10.5962/bhl.title.8547

Rambur MP (1842) Histoire Naturelle des Insectes. Névroptères. Librairie Encyclopédique de Roret, Paris, 534 pp.

Rousseau E, Lestage J-A, Schouteden H (1921) Les larves et nymphes aquatiques des insectes d'Europe (morphologie, biologie, systématique), volume 1. J. Lebègue \& Cie., Bruxelles, 967 pp.

Ulmer G (1951) Köcherfliegen (Trichopteren) von den Sunda-Inseln (Teil 1). Archiv für Hydrobiologie, Supplement 19: 1-528.

Wallace ID, Wallace B, Philipson GN (2003) A key to the case-bearing caddis larvae of Britain and Ireland. Freshwater Biological Association Scientific Publication 61: 1-259.

Waringer J (2003) Light-Trapping of caddisflies at the Thaya (Lower Austria), a river influenced by pulsating hypolimnetic water release. International Review of Hydrobiology 88: 139-153. doi: 10.1002/iroh.200390010

Waringer J, Graf W (2006) Light-trapping of Trichoptera at the March, a lowland river in Eastern Austria. Archives of Hydrobiology, Supplement Large Rivers 16: 351-372.

Waringer J, Graf W (2011) Atlas of Central European Trichoptera Larvae. Erik Mauch Verlag, Dinkelscherben, 468 pp.

Wiberg-Larsen P, Waringer J (1998) A re-description of the larva of Paroecetis strucki (Klapálek, 1903) (Trichoptera: Leptoceridae), based on Danish material. Aquatic Insects 20: 231-238. doi: 10.1076/aqin.20.4.231.4461

Wiggins GB (1996) Larvae of the North American Caddisfly Genera (Trichoptera) (2nd Ed). University of Toronto Press, Toronto, $457 \mathrm{pp}$.

Yang L, Morse JC (2000) Leptoceridae (Trichoptera) of the People's Republic of China. Memoirs of the American Entomological Institute 64: 1-309. 